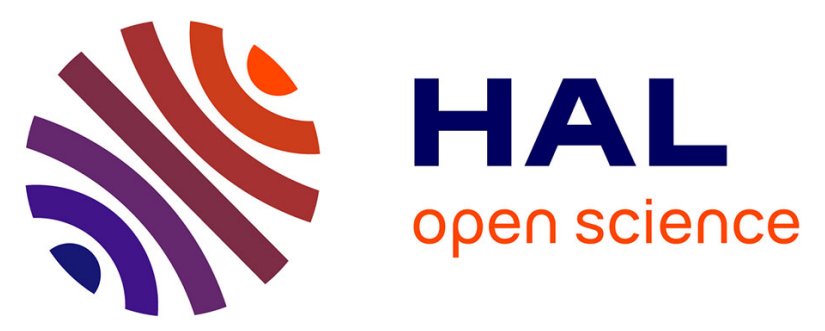

\title{
Decadal variability of sea surface temperatures off North Iceland over the last 2000 years
}

Marie Alexandrine Sicre, Jérémy Jacob, Ullah Ezat, Sonia Rousse, Catherine

Kissel, Pascal Yiou, Jon Eiríksson, Karen Luise Knudsen, Eystein Jansen, Jean-Louis Turon

\section{To cite this version:}

Marie Alexandrine Sicre, Jérémy Jacob, Ullah Ezat, Sonia Rousse, Catherine Kissel, et al.. Decadal variability of sea surface temperatures off North Iceland over the last 2000 years. Earth and Planetary Science Letters, 2008, 268, pp.137-142. 10.1016/j.epsl.2008.01.011 • insu-00311666

\section{HAL Id: insu-00311666 https://hal-insu.archives-ouvertes.fr/insu-00311666}

Submitted on 20 Aug 2008

HAL is a multi-disciplinary open access archive for the deposit and dissemination of scientific research documents, whether they are published or not. The documents may come from teaching and research institutions in France or abroad, or from public or private research centers.
L'archive ouverte pluridisciplinaire HAL, est destinée au dépôt et à la diffusion de documents scientifiques de niveau recherche, publiés ou non, émanant des établissements d'enseignement et de recherche français ou étrangers, des laboratoires publics ou privés. 


\section{Decadal variability of sea surface temperatures off North Iceland over the last 2000 yrs}

Marie-Alexandrine Sicre ${ }^{\mathrm{a}}{ }^{*}$, Jérémy Jacob $^{\mathrm{a}}$, Ullah Ezat ${ }^{\mathrm{a}}$, Sonia Rousse ${ }^{\mathrm{a}}$, Catherine Kissel $^{\mathrm{a}}$, Pascal Yiou $^{\mathrm{a}}$, Jon Eiríksson ${ }^{\mathrm{b}}$, Karen Luise Knudsen ${ }^{\mathrm{c}}$, Eystein Jansen ${ }^{\mathrm{d}}$, Jean-Louis Turon ${ }^{\mathrm{e}}$

${ }^{a}$ Laboratoire des Sciences du Climat et de l'Environnement, IPSL, CNRS/CEA/UVSQ, F-91198 Gif-sur-Yvette, France * corresponding author: sicre@1sce.cnrs-gif.fr; jeremy.jacob@univ-orleans.fr; ezat@1sce.cnrs-gif.fr; Sonia.Rousse@NGU.NO; kissel@1sce.cnrsgif.fr; Yiou@cea.fr

${ }^{\mathrm{b}}$ University of Iceland, IS-101 Reykjavik, Iceland. jeir@hi.is

c Department of Earth Sciences, University of Aarhus, DK-8000 Aarhus, Denmark. karenluise.knudsen@geo.au.dk

d Bjerknes Centre for Climate Research, University of Bergen, Norway. Eystein.Jansen@geo.uib.no

e Département de Géologie et Océanographie, Université de Bordeaux I, Talence, France. turon@epoc.ubordeaux1.fr

\section{Abstract}

Ocean variability at decadal time-scales remains poorly described partly because of the scarcity of high temporal resolution marine records. Here, we present a reconstruction of Sea Surface Temperatures (SSTs) over the past two millennia at unprecedented temporal resolution (2 to 5 years), from a marine core located off North Iceland. Alkenone paleothermometry was used to infer SST variability, and tephrochronology to built the age model. Spectral analyses of the SST signal indicate intermittent 20-25 year oscillations, with periods of strong and weak power, that are likely reflecting the ocean response to wind forcing, presumably the North Atlantic Oscillation (NAO). Warmer SSTs and paleo-magnetic proxy data, between 1000 and 1350 year A.D., overlapping the Medieval Warm Period (MWP), suggest enhanced heat transport across the Denmark Strait by the North Icelandic Irminger Current (NIIC) This is in contrast with the subsequent period, which includes the Little Ice Age (LIA), showing continuous cooling towards the 20th century. Reduced NIIC flow through the Denmark Strait likely resulting from higher freshwater and sea ice export from the Arctic would account for the observed colder conditions.

Keywords. Decadal variability; Sea Surface Temperature; North Atlantic; Alkenones; Medieval Warm Period; Little Ice Age; Iceland 


\section{Introduction}

Understanding ocean variability and how much of it is due to ocean-atmosphere interactions or internal dynamics is a key issue of climate research. In the past decade, numerous studies have focused on the detection of decadal to century time-scale variability in observations and model simulations in order to identify patterns of natural ocean variability in the North Atlantic (Kushnir, 1994; Schlesinger and Ramankutty, 1994; Delworth et al., 1993; 1997; Kaplan et al., 1998, Delworth and Mann, 2000), but the shortness of observational time series prevented from investigating suitably multidecadal variability. Longer duration records resolving ocean variability at the highest possible resolution are thus crucial to improve knowledge of the physical mechanisms with time constants that are those of the ocean/atmospheric coupling and the meridional overturning circulation (MOC). Yet, paleoceanographic proxy records reaching subdecadal resolution and extending back over several centuries to millennia are still sorely lacking, mainly because of the difficulty to obtain undisturbed high sedimentation rate and welldated marine sediments. In this paper, we present a unique 2000 year long Sea Surface Temperature (SST) record obtained at unprecedented temporal resolution (2-5 years) off North Iceland (MD99-2275 core: 66 33N; 17²2W, 470m, average sedimentation rate $250 \mathrm{~cm} / 1000$

years). This site is located in the sub-polar frontal zone, where overlying waters are influenced by the cold and low-salinity waters of the East Greenland Current (EGC) and the Icelandic Current (IC) both flowing southwards, mixing with the warmer and saltier waters of the North Icelandic Irminger Current (NIIC), a branch of the North Atlantic Drift surrounding Iceland by the West (Østerhus et al., 2005) (Figure 1 insert). This region is also highly sensitive to the North Atlantic Oscillation (NAO), the dominant large scale extratropical atmospheric forcing in the Atlantic sector (Hurrell, 1995). Owing to these features, the MD99-2275 core offers the opportunity to capture ocean circulation changes at decadal-scales and investigate their link with NAO.

\section{Methods}

SSTs were estimated using alkenones, which are well established as a valuable tool in paleoceanography (Conte et al., 2006). This biomarker series is biosynthesized by the ubiquitous marine algae Emiliania huxleyi growing in the ocean surface waters. It has been shown by Prahl and Wakeham (1987) that the unsaturation index of the C37 alkenones, UK'37 (C37:2/(C37:2 + C37:3)), is linked to SSTs. UK'37 values were determined along the MD99-2275 core and 
converted into SSTs by applying the most widely used calibration produced by Prahl et al. (1988) $\left(\mathrm{T}=\left(\mathrm{UK}^{\prime} 37-0.039\right) / 0.034\right)$. Alkenones were analyzed following the experimental procedure described in Ternois et al. (1996). Briefly, about $1.5 \mathrm{~g}$ freeze-dried sediments were extracted in an ultrasonic bath for 15 min using a mixture of methylene chloride/methanol $(2: 1 ; \mathrm{v} / \mathrm{v})$. The samples were then centrifuged for $15 \mathrm{~min}$ at $2000 \mathrm{rpm}$ and the supernatant recovered. This operation was repeated two times. The three extracts were combined, concentrated and fractionated into compound classes by silica gel chromatography. Alkenone isolation was performed on $5 \%$ deactivated silica gel and stored in glass vials at $-18^{\circ} \mathrm{C}$ prior to gas chromatographic analyses. Alkenones were analyzed on a Varian Star 3400 CX gas chromatograph equipped a flame ionization detector (FID) and septum programmable injector (SPI), on a fused CP-Sil-5CB silica capillary column $(50 \mathrm{~m}$ x $0.32 \mathrm{~mm}$ i.d., $0.25 \mu \mathrm{m}$ film thickness, Chrompack). The oven temperature was programmed from $100^{\circ} \mathrm{C}$ to $300^{\circ} \mathrm{C}$ at $20^{\circ} \mathrm{C}$ min-1. The analytical precision obtained after repeated injections was calculated to be less than 0.01 unit ratio. Taking advantage of the proximity of major sources of volcanic tephras, reconstruction of an age model with the best possible accuracy was enabled by tephrachronology. Its detailed description can be found in Larsen et al. (2002) and Eiríksson et al. (2004). Eight well-identified tephra layers were used to constrain the age model up to $3000 \mathrm{yrs}$ cal B.P. (Table 1). The tephra layers V 1717, V1477, and V 1410, Hekla 1300 and Hekla 1104 are historically dated, the Settlement layer is dated on the basis of correlations with Grip ice core, while Snæfellsjökull I and Hekla 3 are radiocarbon dated on terrestrial material from Iceland. Due to the overpenetration of the Calypso corer, the upper part of the core was lost during coring operation. The missing portion was estimated to cover the last half-century.

\section{Results}

Figure 1a shows the 2000-year long history of the North Icelandic SSTs plotted as a function of age in calendar years A.D., indicating the tephra age-control points. Earlier water column and sediment trap data have shown that in high latitude oceans, summer is the main season of alkenone production (Sikes et al., 1997; Ternois et al., 1998), thus implying that UK' 37 in the MD99-2275 core is recording summer conditions. The water column alkenone data acquired during the cruise are in agreement with this seasonal pattern (Sicre et al., 2002). Furthermore, the SST estimate of $9^{\circ} \mathrm{C}$ determined in the nearby surface sediment (box-core HM107-2798) is 
consistent with the recent compilation produced by Hanna et al. (2006), reporting that since 1874, July and August SSTs measured at Grimsey island have varied between $6.7^{\circ} \mathrm{C}$ and $9^{\circ} \mathrm{C}$ (see Table 3 in Hanna et al., 2006). The close correspondence between the surface sediment SST value and the instrumental data suggests that alkenones are reliably recording summer SSTs and that potential bias from surface water advection can be ruled out (Conte et al., 2006; Sicre et al., 2005; 2006). Modern SST values also emphasize a significant warming over the past decades.

The North Icelandic SST curve reveals several remarkable features. First, SSTs depict a broad cooling trend towards present, steepening over the last 500 years, with values ranging from $\sim 7$ to $\sim 10{ }^{\circ} \mathrm{C}$. Second, prolonged warm or cool centennial intervals are recognizable among which are the known climatic periods such as the Medieval Warm Period (MWP), the Little Ice Age (LIA), but also the Roman Warm Period (RWP) and cooler Dark Ages. Third, SSTs exhibit unexpected large amplitude oscillations with peak-to-peak difference of $1-2^{\circ} \mathrm{C}$. The temporal characteristics of this signal were quantified by Morlet wavelet analysis to provide information on how features of variability evolve with time. We also computed spectral power with the multi-taper method developed by Ghil et al. (2002) over the whole time series to estimate statistical significance of peaks (Figure 2). Results reveal a dominant variability around 20-25 year period with distinct strong and weak energy intervals, and some power in the multidecadal range that is poorly characterized. High energy at the 20-25 year band is more pronounced in the early (0-200 A.D) and late (1250-1950 A.D.) portion of the record, and notably during the LIA.

\section{Discussion}

\subsection{Medieval Warm Period and Little Ice Age}

A remarkable feature of the North Icelandic SST record is the abrupt increase of $\sim 1-1.5^{\circ} \mathrm{C}$ occurring within a decade 980 A.D., maybe imputable to the onset of the MWP. This sustained warm period, lasting for several centuries, ends by a sharp cooling 1350 A.D., following a brief cold episode $\sim 1250$ A.D. The same pronounced centennial scale warming, though not exactly synchronous, has been documented by the distant records from the Sargasso Sea (Keigwin, 1996), the Eastern sub-tropical Atlantic (deMenocal et al., 2000) and estuarine sediments of Chesapeake bay (Cronin et al., 2005), confirming its widespread occurrence in the North Atlantic region. A rise in the titanium content in the tropical Atlantic Cariaco basin sediments at $\sim 930$ 
A.D. has also been reported, from which a northwards shift of the ITCZ and MOC change were inferred (Haug et al., 2001). Indeed, strong MOC generates a cross equatorial SST gradient that causes the ITCZ to move northward (Vellinga and $\mathrm{Wu}, 2004$ ).

In order to investigate the links between the North Icelandic SSTs and ocean circulation changes, anhysteretic remanent magnetization (ARM), isothermal remanent magnetization (IRM) and volumic low field susceptibility $(k)$ were measured along our core. In an earlier study, Rousse et al. (2006) have shown that, in core MD99-2275, the magnetic mineralogy is uniformly made of magnetites, allowing the use of the ARM/ $k$ or ARM/IRM ratios to deduce changes in the magnetite grain size, and ARM to trace changes in the concentration of fine grain magnetites. These parameters in core MD99-2275 were thus utilized to identify time spans of major ocean circulation changes at the site. Lower concentrations of fine-grained magnetites associated to coarser grains are indicative of stronger currents. The ARM/k or ARM/IRM plots, shown in Figure 1b, suggest a general slowdown tendency of the ocean circulation over the past 2000 years, but more vigorous bottom currents during most of the warmer period off North Iceland, between 1000-1300 A.D., likely reflecting enhanced NIIC inflow. The NIIC is one of the three branches of the North Atlantic Drift (NAD) entering the Greenland-Iceland-Norwegian seas (GINS) and the major heat source for the North Icelandic shelf waters (Østerhus et al., 2005). The NIIC transport rate and subsequent heat flux strongly control temperature changes North of Iceland. A higher NIIC flow rate through the Denmark Strait results in enhanced heat transport towards the North Icelandic shelf, while a lower flow causes SSTs to decrease. The basin-wide recognition of the MWP temperature anomaly in the North Atlantic basin and associated more northerly position of the ITCZ lead us to hypothesize a strengthening of the MOC.

This period contrasts with the cold SSTs and enhanced 20-25 cycles of the LIA. Large cooling of the surface waters can result from heat exchange at the surface ocean by vertical mixing under strong wind conditions. Several proxy record sources already suggested that during the LIA, latitudinal gradients would have been steeper and westerly winds more intense, which at a basinscale, would result in larger heat loss to the atmosphere (Keigwin, 1996; Kreutz et al., 1997; Hendy et al., 2002). On a regional scale, observations combined to high-resolution modelling investigations have recently shown that the NIIC flow rate across the Denmark Strait is largely controlled by local wind fields (Logemann and Harms, 2006). NIIC northwards transport 
increases when the northerly component of local winds blowing across the strait decreases, while it significantly reduces or suppresses when northerly winds reinforce the EGC. Under extreme conditions, the EGC broadens to reach the point to even block the NIIC passage across the Denmark Strait. This was presumably the case between 1685-1704 during the severe phase of the LIA, where lowest temperature values were found at the time of the Maunder sunspot minimum (1680-1730 A.D.) (Lamb, 1979). Icelandic records indicate that ice began to be more prominent after 1200 year A.D. and that no vessels could reach the East Greenland coast from 1476 to 1822 (Lamb, 1979). Wind forcing is thus an important parameter for the northwards heat transport by the NIIC as well as the southwards transport of polar waters and sea ice from the Arctic by the EGC, through the Denmark Strait. It is likely that persistent conditions of high EGC import of freshwater waters from the Arctic could have contributed to alter buoyancy and decrease deepwater formation in the GINS. Recent data from Lund et al. (2006) have shown reduced MOC transport across the Florida Strait, by about to $10 \%$, during the LIA. The southern shift of the ITCZ over that period, as revealed by the Cariaco record, further supports this idea and lead us to hypothesize that lower MOC during the LIA would have been caused by the massive intrusion of freshwater and sea ice from the Arctic.

\subsection{Decadal variability}

A near 20-year period has been found in various observation or proxy records such as the intensity of the winter zonal atmospheric circulation (Von Storch et al., 1993), the temperatures in central England (Folland, 1983; Plaut et al., 1995) and tree ring reconstructions (Mann et al., 1995; Cook et al., 1998), among others. These times series reproduce the lower frequencies evidenced in the NAO index spectrum, i.e. 24 and 8 years, suggesting a link between the short time scale variability of North Icelandic SSTs and NAO (Roger, 1984; Hurrell and Van Loon, 1997). However, multidecadal variability has been identified as the dominant mode of SST variability and linked to fluctuations of the MOC (Latif et al., 2004; Knight et al., 2005), while in

our record such oscillations are poorly defined and less significant. A recent 1600-year simulation of the MOC variability by HadCM3 model (Third Hadley Center Coupled OceanAtmosphere General Circulation Model) has shown strong variance at time scales of 70-200 years and, intermittently, at 10-30 years (Vellinga and $\mathrm{Wu}, 2004$ ). As opposed to the North Icelandic SST time series, centennial scale variability in this simulation was the dominant 
oscillatory mode of internal MOC variability, a difference that could reflect the regional character of the North Icelandic SST time series and the predominant fingerprint of NAO forcing at this latitude. A high-resolution paleo-record documenting climate variability of the last millennia to which our data can be compared is from the mid-latitude Chesapeake Bay estuarine sediments, Eastern US (Cronin et al., 2005). Multi-taper analyses of the precipitation and temperature proxy records reconstructed at this site both indicate a strong variability around 40-80 year period in the early Holocene, shifting towards shorter 20-30 year period during the late Holocene (Cronin et al., 2005). Strong bi-decadal variability in the Chesapeake Bay time series is consistent with our data and further supports the idea of a link with NAO, and its stronger influence during the recent past. It is quite well-established that atmospheric processes drive North Atlantic SSTs at subdecadal time scales. Atmospheric forcing produces perturbations that can be communicated by the main circulation and propagate in the North Atlantic within a few years. However, the exact link between NAO patterns, including the possible shift of its center of actions (Hilmer and Jung, 2000), and the ocean variability needs to be further explored within the instrumental period and paleo-records. Recent studies have shown that on decadal time scales, high NOA induces deeper convection in the Labrador Sea (Latif et al., 2006) and Irminger Sea (Pickart et al., 2003) and can therefore impact on the MOC variability (Latif et al., 2006). We speculate that during the LIA, NAO may have played a role by partly influencing the variation of sea ice and freshwater outflow from the Arctic, through the EGC.

\section{Conclusion}

This study demonstrates that shelf sediments can provide exceptional archives of the past climate and ocean circulation. The high-resolution North Icelandic SST time series reconstructed from

alkenones has shown unexpected strong variability with bidecadal oscillations (20-25 years) comparable to those identified in the Late Holocene Chesapeake Bay sediments. These oscillations would primarily reflect the ocean response to NAO forcing. Colder conditions during the LIA could result from heat loss to the atmosphere due to stronger Westerly winds and/or a decline of the MOC as earlier suggested by Lund et al (2006). Enhanced export of freshwater and sea ice from the Arctic could have triggered a significant reduction of the deep-water formation, and subsequently of MOC, leading to severe LIA climate conditions. We speculate that NAO could have influenced the variations of the freshwater flow out of the Arctic. In contrast, during 
the MWP, NIIC would have been stronger causing the observed $1.5^{\circ} \mathrm{C}$ warming off North Iceland. Future work on this core will focus on extending the reconstruction of SSTs to investigate the 3000-4000 years B.P. time interval where abrupt and large amplitude shifts of the ITCZ are seen in the Cariaco record, and on the 8200 year meltwater event.

\section{Acknowledgments}

We are grateful to the French Polar institute IPEV for providing the IMAGES program the facilities during the IMAGES-Ginna cruise in 1999 on the Research vessel Marion Dufresne. We are particularly thankful to the crew with special mention to Yvon Balut, recently retired, for the development and operation of the Calypso corer during all these years. This paper is a contribution of the PACLIVA European Commission $5^{\text {th }}$ Framework Program (Contract EVK22002-00143). This is LSCE contribution number XX.

\section{References.}

Conte, M.H., Sicre, M.-A., Rühlemann, C., Weber, J. C., Shultz-Bull, D., Blanz, T., 2006. Global temperature calibration of the alkenone unsaturation index (UK'37) in surface waters and comparison with surface sediments Geochem. Geophys. Geosyst. 7(2) doi:1029/2005GC001054.

Cook, E.R., D’Arrigo, R.D., Briffa, K.R., 1998. A reconstruction of the North Atlantic Oscillations using tree-ring chronologies from North America and Europe. The Holocene 8, 9-17.

Cronin, M.T., Thunell, R., Dwyer, G.S., Saenger, C., Mann, M.E., Vann, C., Seal II, R.R., 2005. Multi-proxy evidence of Holocene climate variability from estuarine sediments, eastern North America. Paleoceanography 20, doi:10.1029/2005PA001145.

Delworth, T., Manabe, S., Stouffer, R.J., 1993. Interdecadal variations of the thermohaline circulation in a coupled ocean-atmosphere model. J. Clim. 6, 1993-2011.

Delworth, T., Manabe, S., Stouffer, R.J., 1997. Multidecadal climate variability in the Greenland Sea and surrounding regions: a coupled model simulation. Geophys. Res. Lett. 24, 257-260.

Delworth, T., Mann, M.E., 2000. Observed and simulated multidecadal variability in the Northern Hemisphere. Clim. Dyn. 16, 661-676.

deMenocal, P., Ortiz, J., Guilderson, T., Sarnthein, M., 2000. Coherent high and lowlatitude climate variability during the Holocene warm period. Science 288, 2198-2202. 
Eiríksson, J., Larsen, G., Knudsen, K. L., Heinemeier, J., Símonarson, L., 2004. Marine reservoir age variability and water mass distribution in the Iceland Sea. Quat. Sci. Rev. 23, 2247-2268.

Folland, C.K., 1983. Regional-scale interannual variability of climate - a northwest European perspective. Meteorological Magazine 112, 163-183.

Ghil, M., Allen, M.R., Dettinger, M.D., Ide, K., Kondrashov, D., Mann, M.E., Robertson, A.W., Saunders, A., Tian, Y., Varadi, F., Yiou, P., 2002. Advanced spectral methods for climatic time series. Rev. Geophys. 40, 1, 1-41.

Hanna, E., Jonsson, T., Olafsson, J., Vladimarsson, H., 2006. Icelandic coastal sea surface temperature records constructed: putting the pulse on Air-Sea-Climate Interactions in the Northern North Altantic. Part I: Comparison with HadISST1 open ocean surface temperatures and preliminary analysis of long-term patterns and anomalies of SSTs around Iceland. J. of Climate 19, 5652-5666.

Haug, G.H., Hughen, K.A., Sigman, D.M., Peterson, L.C., Röhl, U., 2001. Southward migration of the Intertropical convergence zone through the Holocene, Science 293, 1304- 1308.

Hendy, E.J., Gagan, M.K., Alibert, C.A., McCulloch, M.T., Lough, J.M., Isdale, P.J., 2002. Abrupt decrease in tropical Pacific sea surface salinity at end of Little Ice Age. Science 295, 1511-1514.

Hilmer, M., Jung, T., 2000. The link between the North Atlantic oscillation and Artic sea ice export through Fram strait, J. of Clim. 14, 3932-3943.

Hurrell, J.W., 1995. Decadal trends in the North Atlantic Oscillation: regional temperature and precipitation. Science 269, 676-679.

Hurrell, J., Van Loon, H., 1997. Decadal variations in climate associated with the North Atlantic Oscillation. Clim. Change 301-326.

Jonsson, S., Valdimarsson, H., 2005. The inflow of Atlantic water to the North Icelandic shelf and its relation to the drift of cod larvae. ICES J. of Mar. Sci. doi :10.1016/j.icesjms.2005.05.03.

Kaplan, A., Cane, M.A., Kushnir, Y., Clement, A.C., Blumenthal, M.B., Rajagopalan, B., 1998. Analyses of global sea surface temperature 1856-1991. J. Geophys. Res. 103, 18567-18589.

Keigwin, L.D., 1996. The little ice age and medieval warm period in the Sargasso Sea, Science 274, 1504-1508.

Knight, J.R., R.J., Allan, CK., Folland, M., Vellinga, M.E., Mann, 2005. A signature of persistent natural thermohaline circulation cycles in observed climate. Geophys. Res. Lett. 32, L20708, doi: 10.1029/2005GL024233. 
Kreutz, K.J., Mayewski, P.A., Meeker, L.D., Twickler, M.S., Whitlow, S.I., Pittalwala, I.I., 1997. Bipolar changes in atmospheric circulation during the Little Ice Age. Science 277, 1294-1296.

Kushnir, Y., 1994. Interdecadal variations in North Atlantic Sea surface temperature and associated atmospheric conditions. J. Clim. 7, 141-157.

Lamb, H., 1979. Climatic variation and changes in the winds and ocean circulation: The Little Ice Age in the Northeast Atlantic. Quat. Res. 11, 1-20.

Larsen, G., Eiríksson, J., Knudsen, K. L., Heinemeier, J., 2002. Correlation of late Holocene terrestrial and marine tephra markers, north Iceland: implications for reservoir age changes. Polar Research 21, 283-290.

Latif, M., E., Botzet, M.,Esch, H., Haak, S., Hagemann, J., Jungclaus, S., Legutke, S., Marsland, U., Mikolajewicz, J., Mitchell, 2004. Reconstructing, monitoring and predicting multidecadal-scale changes in the North Atlantic thermohlaine circulation with sea surface temperature. J. of Climate 17, 1605-1614.

Latif, M., Böning, C., Willebrand, J., Biastoch, A., Dengg, J., Keenlyside, N., Schweckendiek, U., 2006. Is the thermohaline circulation changing? J. Climate 19, 4631-4637.

Logemann, K., Harms, I.H., 2006. High resolution modelling of the North Icelandic Irminger Current (NIIC). Ocean Science Discussion 3, 1149-1189.

Lund, D.C., J. Lynch-Steiglitz, W.B. Curry, 2006. Gulf Stream density structure and transport during the last millennium. Nature 444, 601-604.

Mann, M.E., Park, J., Bradley, R.S., 1995. Global interdecadal to century-scale climate oscillations during the past five centuries. Science 378, 266-270.

Østerhus, S., Turell, W.R., Jonsson, S., Hansen, B., 2005. Measured volume, heat, and salt fluxes from the North Atlantic to the Arctic Mediterranean. Geophys. Res. Lett. 32, doi:10.1029/2004GL022188.

Pickart, S., Spall, M.A., Ribergaard, M.H., Moore, G.W.K., Milliff, R.F., 2003. Deep convection in the Irminger Sea forced by the Greenland tip jet. Nature 424, 152-156.

Plaut, G., Ghil, M., Vautard, R., 1995. Interannual and interdecadal variability in 335 years of central England temperature. Science 268, 710-713.

Prahl, F. G., and S. G. Wakeham, Calibration of unsaturation patterns in long-chain ketone compositions for palaeotemperature assessment, Nature, 330, 367-369, 1987. 
Prahl, F.G., Muehlhausen, L.A, Zahnle, D.L., 1988. Further evaluation of long-chain alkenones as indicators of paleoceanographic conditions. Geochim. Cosmochim. Acta 52, 2303-2310.

Roger, J.C., 1984. The association between the North Atlantic Oscillation and the Southern Oscillation in the Northern Hemisphere. Monthly Weather Review 112, 1999-2015.

Rousse, S., Kissel, C., Laj, C., Eiríksson, J., Knudsen, K.L., 2006. Holocene centennial to millennial-scale climatic variability: evidence from high-resolution magnetic analyses of the last 10 cal kyrs off North Iceland (core MD99-2275). Earth Planet. Sci. Lett. 242, 390-405.

Schlesinger, M., Ramankutty N., 1994. An oscillation in the global climate system of period 65-70 years. Nature 367, 723-726.

Sicre, M.-A., Bard, E., Ezat, U., Rostek, F., 2002. Alkenone distributions in the North Atlantic and Nordic sea surface waters, Geochemistry, Geophysics, Geosystems, 3 (2), 2001GC000159, 1-13.

Sicre, M-A, Labeyrie, L., Ezat, U., Duprat, J., Turon, J-L., Schmidt, S., Michel, E., Mazaud A., 2005. Mid-Latitude southern ocean response to northern hemisphere Heinrich events. Earth and Planet. Sci. Lett. 240, 724-731.

Sicre, M-A, Labeyrie, L., Ezat, U., Duprat, J., Turon, J-L., Schmidt, S., Michel, E., Mazaud A., 2006. Erratum to: Mid-Latitude southern ocean response to northern hemisphere Heinrich events. Earth and Planet. Sci. Lett. 243, 303-304.

Sikes, E.L., Volkman, J.K., Robertson, L.G., Pichon J.-J., 1997. Alkenones and alkenes in surface waters and sediments of the Southern Ocean: Implications for paleotemperature estimation in polar regions. Geochim. Cosmochim. Acta 61, 1495-1505.

Ternois Y., Sicre M.-A , Boireau A., Marty J-C and Miquel J.C., 1996. Production pattern of alkenones in the Mediterranean Sea. Geophysical Research Letters 23, 3171-3174.

Ternois, Y., Sicre, M.-A., Boireau, A., Beaufort, L., Miquel, J.-C., Jeandel, C., 1998. Hydrocarbons, sterols and alkenones in sinking particles in the Indian sector of the Southern Ocean. Org. Geochem. 28, 489-501.

Timmermann, A., Goose, H., 2004. Is the wind stress forcing essential for the meridional overturning circulation? Geophys. Res. Lett. 31, doi:10.1029/2003GL018777.

Vellinga, M., P. Wu, 2004. Low-latitude freshwater influence on centennial variability of the North Atlantic circulation. J. of Climate, 4498-4511.

Von Storch, H., Zorita, E., Cubasch, U., 1993. Downscaling of global climate change estimates to regional scales: an application to Iberian rainfall in wintertime. J. Clim. 6, 1161-1171. 


\section{Figure Captions}

Figure 1: (a) High resolution Sea surface temperature (in ${ }^{\circ} \mathrm{C}$ ) derived from alkenone paleothermometry versus age A.D., over the last 2000 yr B.P. Temporal resolution of the blue curve is ranging from 2 to 5 years. The superimposed red curve is a 5 points running mean. Major known historical periods are reported. Back squares indicate tephra layers used to establish the age model. (b) The pink curve shows the ARM values and the dark blue curve plots the ARM/k ratio values (Rousse et al., 2006).

Figure 2: Results of spectral analyses of alkenone derived Sea Surface Temperature (SSTs) along the MD99-2275 core. We performed a continuous wavelet analysis of the data, using a Morlet wavelet. This analysis enables us to distinguish how the features of variability evolve with time. Spectral power was computed with a multi-taper method (Ghil et al., 2002) to estimate significance of peaks. Red noise tests were performed in order to assess the significance of the particular frequencies/periods present in the SST time series. The colored lines indicate the confidence interval for red noise tests. 


\begin{tabular}{cccl}
\hline $\begin{array}{c}\text { Depth } \\
\text { (in cm) }\end{array}$ & $\begin{array}{c}\text { Age, } \\
\text { ( cal. BP) }\end{array}$ & $\begin{array}{c}\text { Age, AD/BC } \\
\text { (in AD/AC) }\end{array}$ & Marker horizons \\
\hline 101 & 230 & 1720 & Veidivötn AD 1717 \\
179 & 470 & 1480 & Veidivötn AD 1477 \\
209 & 540 & 1410 & Veidivötn AD 1410 \\
239 & 650 & 1300 & Hekla AD 1300 \\
275 & 850 & 1100 & Hekla AD 1104 \\
321 & 1080 & 870 & Settlement Layer \\
460 & 1818 & 132 & Snæfellsjökull I \\
687 & 2980 & 1030 & Hekla 3 \\
\hline
\end{tabular}

Table 1 : Depth in centimeters $(\mathrm{cm})$, ages in year cal BP and in year AD of the tephra layers identified in core MD99-2275 used to build the age model. 


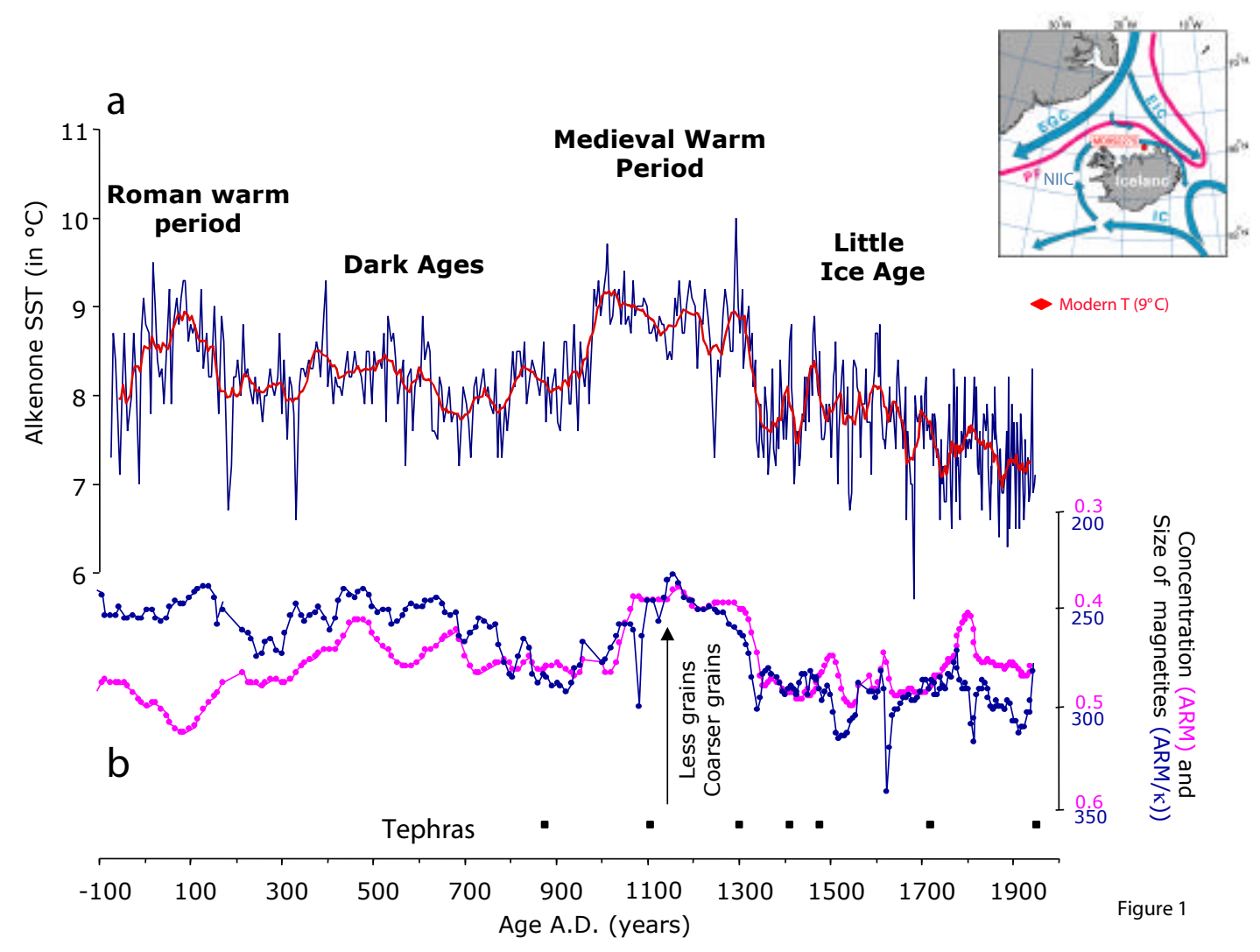


Figure 2
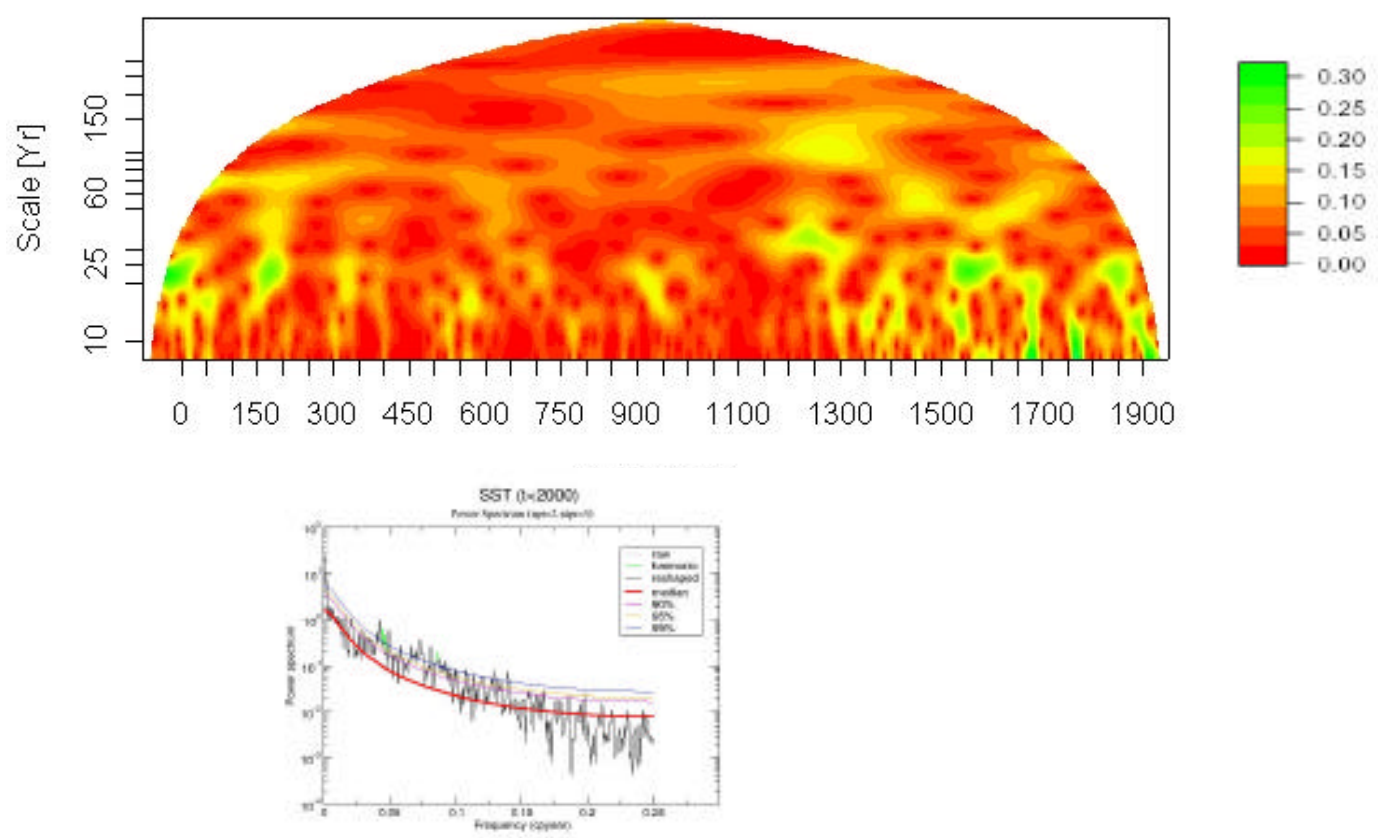